\title{
ABLATION OF A LEFT-SIDED WPW IN A PATIENT WITH PERSISTENT LEFT SUPERIOR VENA CAVA
}

\section{АБЛАЦИЈА НА ЛЕВОСТРАН ДОПОЛНИТЕЛЕН ПАТ КАЈ ПАЦИЕНТ СО WРЖ СИНДРОМ И ЛЕВА ПЕРЗИСТЕНТНА VENA KAVA SUPERIOR}

\author{
Dejan Risteski and Borjanka Taneva \\ University Clinic of Cardiology, University "Ss. Cyril and Methodius", Medical Faculty, Skopje, Republic of \\ Macedonia
}

\begin{abstract}
Anomalies of the venous system may impose serious limitations to the treatment of arrhythmias by means of ablation therapy. We describe a patient who had WPW syndrome with frequent supraventricular tachycardias in whom an ablation was performed. The patient was found to have a persistent left superior vena cava and a left-sided manifest accessory pathway. Persistent left superior vena cava is the most common congenital thoracic venous anomaly with a prevalence of $0.3-0.5 \%$ in the general population and is found more frequently in patients with accessory pathways than in patients with AV nodal reentrant tachycardia. Mapping and ablation of an accessory pathway follows the same general electrophysiology principles applicable to patients without anomalous venous return.
\end{abstract}

Key words: Wolff-Parkinson-White, accessory pathway, left persistent superior vena cava

\section{Апстракт}

Аномалиите на венскиот систем на срцето можат сериозно да влијаат на третманот на срцевите аритмии особено кај аблационата терапија. Ние прикажуваме случај со WPW синдром со чести предкоморни тахикардии кај кој беше направена аблација на дополнителниот пат. Кај пациентот се дијагностицира лева перзистентна вена кава супериор и левостран манифестен дополнителен пат. Лева перзистентна вена кава супериор претставува најчеста конгенитална аномалија на венскиот систем на срцето со преваленција 0,3-0,5\% од популацијата и е многу почеста кај пациенти кај кои се дијагностицира атриовентрикуларен дополнителен пат во споредба со оние кај кои постои атриовентрикуларна јазолна кружна

\footnotetext{
Correspondence to: Dejan Risteski, University Clinic of Cardiology, "Vodnjanska" 17, 1000 Skopje, R. Macedonia; Phone: 072231 086;

E-mail: dr.dristeski@yahoo.com
}

тахикардија. Електрофизиолошкото мапирање и аблацијата на дополнителниот пат беше идентично во споредба со оние пациенти кај кои не постојат аномалии на венскиот систем на срцето.

Клучни зборови: Волф-Паркинсон-Вајт синдром, дополнителен пат на срцето, лева перзистентна вена кава супериор

\section{Introduction}

Persistent left superior vena cava (PLSVC) is an uncommon vascular anomaly; however, it is the most common congenital thoracic venous anomaly with a prevalence of $0.3-0.5 \%$ in the general population [1]. It results when the left superior cardinal vein caudal to the innominate vein fails to regress. It is most commonly observed in isolation but can be associated with other cardiovascular abnormalities including atrial septal defect, bicuspid aortic valve, coarctation of aorta, coronary sinus ostial atresia, and cor triatriatum [2].

\section{Case report}

A 46-year-old man was referred for catheter ablation of short QRS tachycardia for recurrent presyncopal spells. Normal valve and left ventricular function were assessed with echocardiography. The following catheters were inserted through the femoral veins (three from right femoral vein and one from left femoral vein): quadripolar catheters were placed in the right ventricular apex, His bundle and high right atrium; a decapolar catheter (Biosence Webster G curve) was placed easily in the CS. Baseline underlying electrophysiology parameters were as follows: $\mathrm{AH}=110 \mathrm{msec} ; \mathrm{HV}=33 \mathrm{msec}$. The accessory pathway has antegrade and retrograde conduction. The pathway effective refractory period was $300 \mathrm{~ms}$ at 600 ms pacing drive train from the right ventricular apex. Atrioventricular reentrant tachycardia was induced with programmed stimulation from CS 5,6 at 600/500/320 msec, TCL $380 \mathrm{msec}$ (155 bpm), eccentric retrograde 
atrial activation with CS 1,2 earliest point of activation. The accessory pathway was found as left lateral.

\section{Discussion}

The presence of PLSVC can render access to the right side of heart challenging via the left subclavian approach. Major coronary sinus abnormalities were found more frequently in patients with accessory pathways than in patients with AV nodal reentrant tachycardia [3].
The presence of an accessory pathway in the event of PLSVC could be explained by a common embryogenic development (Figure 1). Failure of the left superior cardinal vein to regress, i.e. the ligament of Marshall, results in PLSVC (Figure 2). In the same fashion, accessory pathways may result from failure of resorption of the myocardial syncytium at the annulus fibrosis of the atrioventricular valves during fetal development [4,5].
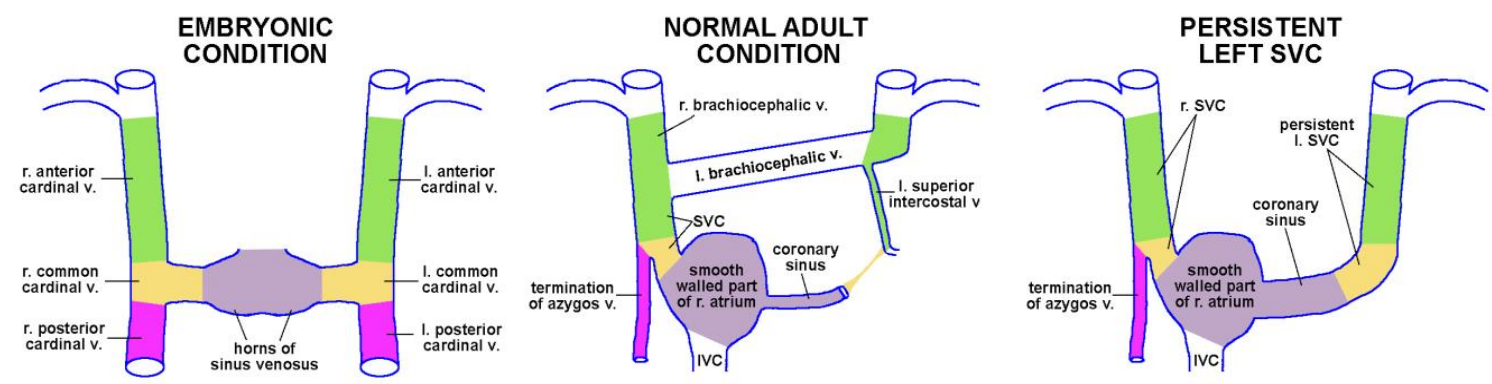

Fig. 1. Embryogenic development of Persistent Left Vena Cava Superior

We prepared trans-septal puncture and placed ablation catheter on mitral valve with AV fusion on ablation catheter and the unipolar electrocardiograms showed rapid and deep QS, and there was a possible accessory pathway potential (Figure 3). One application of RF (temperature $=58^{\circ}$; power $=58$ watts; temperature control mode) at this site abolished pathway within six seconds. No delta wave on ECG (Figure 4 and 5). Four more applications of RF (safety burns) were done, each lasted for 30 seconds. Twenty minutes later there was VA dissociation at $520 \mathrm{msec}$ and ECG without delta wave.
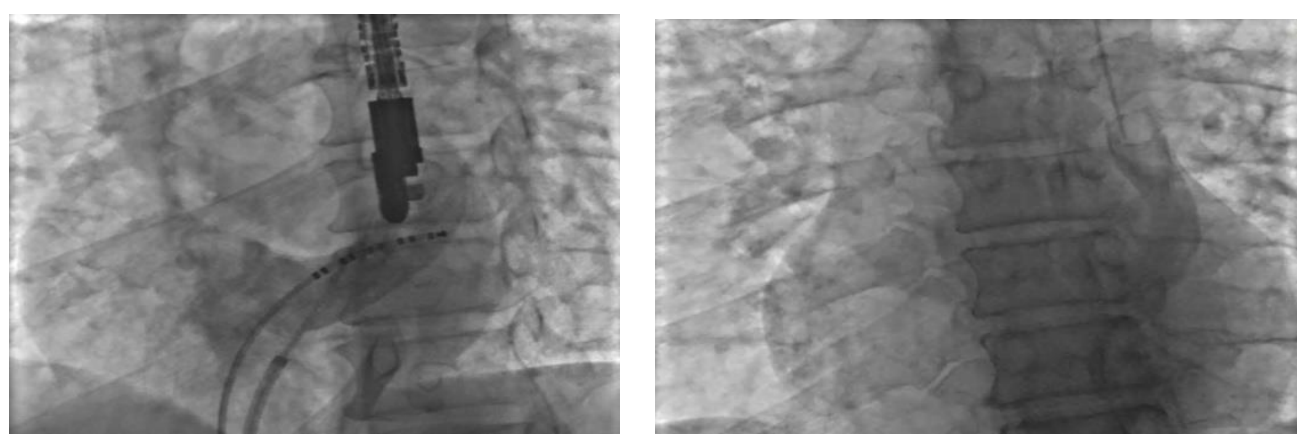

Fig. 2. Persistent Left Vena Cava Superior confirmed by subsequent venography

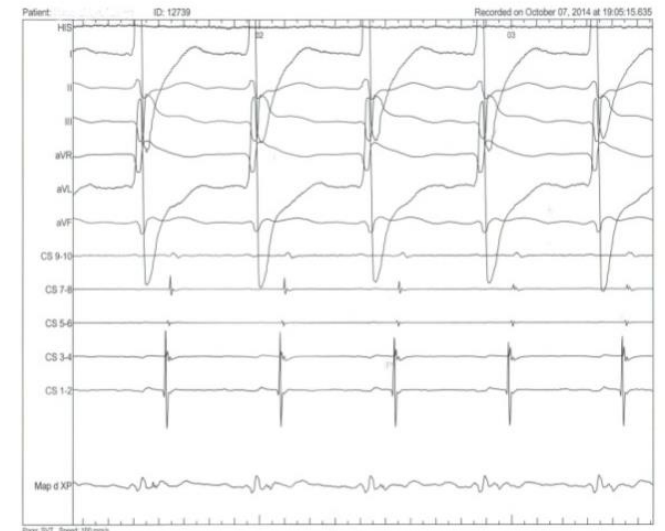

Fig. 3. Intracardial ECG of WPW with Left accessory pathway

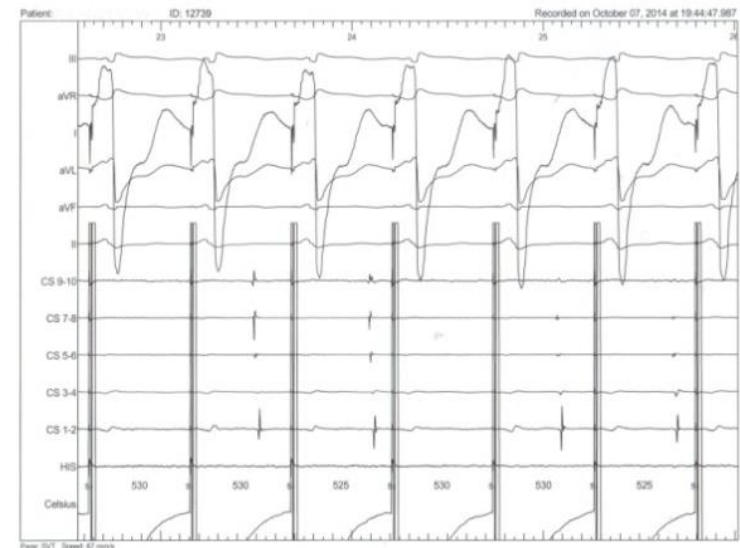

Fig. 4. Intracardial ECG of VA dissociation at $520 \mathrm{msec}$ after ablation of Left accessory pathway 


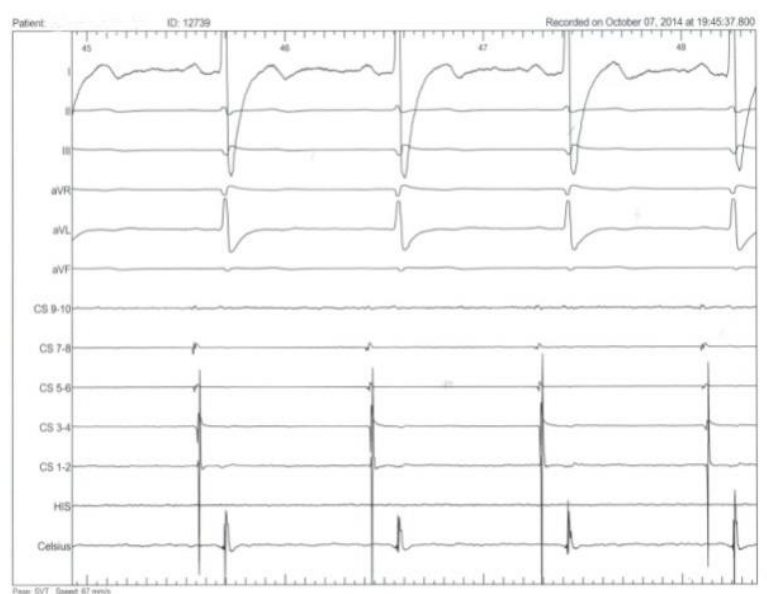

Fig. 5. End of procedure. No delta wave,concentric activation of atrial signal at CS catheter

\section{Conclusion}

PLSVC is the most frequent congenital thoracic vein abnormality. PLSVC is suspected where there is dilation of the CS in the absence of a cause for elevated right atrial pressure. Mapping and ablation of an accessory pathway in patients with PLSVC follows the same general electrophysiology principles applicable to patients without anomalous venous return.

Conflict of interest statement. None declared.

\section{References}

1. Pahwa R, Kumar A. Persistent left superior vena cava: an intensivist's experience and review of the literature. South Med J 2003; 96: 528-529.

2. Danielpour PJ, Aalberg JK, El-Ramey M, et al. Persistent left superior vena cava: an incidental finding during central venous catheterization-a case report. Vasc Endovascular Surg 2005; 39: 109-111.

3. Gonzalez-Juanatey C, Testa A, Vidan J, et al. Persistent left superior vena cava draining into the coronary sinus: report of 10 cases and literature review. Clin Cardiol 2004; 27: 515-518.

4. Haissaguerre M, Warin JF. Closed-chest ablation of left lateral atrioventricular accessory pathways. Eur Heart $J$ 1989; 10: 602-610.

5. Katsivas A, Koutouzis M, Nikolidakis S, et al. Persistent left superior vena cava associated with common type AV nodal reentrant tachycardia and AV reentrant tachycardia due to concealed left lateral accessory pathway. Int J Cardiol 2006; 113: e124-e125. 